\title{
Dual Actions of Ketorolac in Metastatic Ovarian Cancer
}

\author{
Laurie G. Hudson ${ }^{1, *, \dagger}$, Linda S. Cook ${ }^{2,+}$, Martha M. Grimes ${ }^{1} \mathbb{D}$, Carolyn Y. Muller ${ }^{3}$, \\ Sarah F. Adams ${ }^{3}$ and Angela Wandinger-Ness 4 (D) \\ 1 Department of Pharmaceutical Sciences, University of New Mexico Health Sciences Center, \\ Albuquerque, NM 87131, USA \\ 2 Department of Internal Medicine, Division of Epidemiology and Biostatistics, University of New Mexico \\ Health Sciences Center, Albuquerque, NM 87131, USA \\ 3 Department of Obstetrics and Gynecology, Division of Gynecologic Oncology, University of New Mexico \\ Health Sciences Center, Albuquerque, NM 87131, USA \\ 4 Department of Pathology, University of New Mexico Health Sciences Center, Albuquerque, NM 87131, USA \\ * Correspondence: lhudson@salud.unm.edu; Tel.: +1-505-272-2482 \\ + Authors contributed equally to this paper.
}

Received: 24 June 2019; Accepted: 17 July 2019; Published: 24 July 2019

check for updates

\begin{abstract}
Cytoreductive surgery and chemotherapy are cornerstones of ovarian cancer treatment, yet disease recurrence remains a significant clinical issue. Surgery can release cancer cells into the circulation, suppress anti-tumor immunity, and induce inflammatory responses that support the growth of residual disease. Intervention within the peri-operative window is an under-explored opportunity to mitigate these consequences of surgery and influence the course of metastatic disease to improve patient outcomes. One drug associated with improved survival in cancer patients is ketorolac. Ketorolac is a chiral molecule administered as a 1:1 racemic mixture of the S- and R-enantiomers. The S-enantiomer is considered the active component for its FDA indication in pain management with selective activity against cyclooxygenase (COX) enzymes. The R-enantiomer has a previously unrecognized activity as an inhibitor of Rac1 (Ras-related C3 botulinum toxin substrate) and Cdc42 (cell division control protein 42) GTPases. Therefore, ketorolac differs from other non-steroidal anti-inflammatory drugs (NSAIDs) by functioning as two distinct pharmacologic entities due to the independent actions of each enantiomer. In this review, we summarize evidence supporting the benefits of ketorolac administration for ovarian cancer patients. We also discuss how simultaneous inhibition of these two distinct classes of targets, COX enzymes and Rac1/Cdc42, by S-ketorolac and R-ketorolac respectively, could each contribute to anti-cancer activity.
\end{abstract}

Keywords: ovarian cancer; peri-operative period; non-steroidal anti-inflammatory drug (NSAID); ketorolac; Rac1; Cdc42; therapeutic targets; metastasis

\section{Introduction}

From 1975-2014 in the US, 5-year relative survival for invasive ovarian cancer has increased from $33.6 \%$ to $46.8 \%$ [1]. Annual age-adjusted death rates have dropped from 9.84/100,000 to 6.74/100,000 paralleling a drop in incidence in the same time period [1], but this mortality drop is modest relative to the 5-year survival increase. These patterns highlight that 5-year survival has increased substantially, but annual mortality has only dropped modestly. Women are surviving longer due to improved treatment, but there is little improvement in overall survival in late-stage disease [2]. Ovarian cancer remains the leading cause of death from gynecologic malignancy, primarily due to the emergence of drug resistant disease following front-line surgery and systemic chemotherapy [3-8]. 
The mainstays of ovarian cancer treatment include a defined combination of surgery and chemotherapy. Front line systemic chemotherapy includes platinum compounds and taxanes, with doxorubicin, topotecan, and gemcitabine as options in recurrent disease [9]. Additional therapies including anti-angiogenics and poly (ADP ribose) polymerase (PARP) inhibitors have been added to treatment regimens with the goal of extending the disease-free interval $[9,10]$. More recently, immunotherapies are being evaluated in clinical trials. Benefits of PARP inhibitors are most successful in the minority of patients carrying germline BRCA1/2 mutations [11], but currently less so in the broader ovarian cancer patient population [10]. Immune therapies targeting checkpoint blockades yield mixed results in clinical trials and toxicity is a concern [10]. There are ongoing efforts to identify new actionable targets in ovarian cancer and expand the therapeutic repertoire for this disease [3-5,7-9,12].

A range of strategies needs to be considered to improve the outcomes for ovarian cancer patients. In recent years, the peri-operative period has received greater attention as a unique and largely overlooked opportunity for intervention in cancer treatment. Surgery modifies the tumor environment in ways that may promote tumor cell dissemination, survival, and expansion [13-18]. Research has identified candidate mechanisms and the potential for therapeutic interventions to allay the consequences of surgery on tumor recurrence $[15,17,18]$. Although retrospective studies provide support for greater attention on the peri-operative window, randomized-control clinical trials are needed to resolve the potential of peri-operative strategies to improve cancer patient outcomes. In subsequent sections, we discuss supporting evidence of the benefits of peri-operative ketorolac administration in cancer patients and underlying mechanisms that may account for these observations in ovarian cancer.

\section{Cancer Surgery and Metastasis}

\subsection{Peritoneum is a Site for Residual Disease}

Ovarian cancer, like many epithelial cancers, spreads by direct extension to adjacent organs. However, and in contrast with many other cancers, ovarian cancer also disseminates throughout the peritoneal (abdominal and pelvic) cavity $[4,19,20]$. Tumor cells that detach from the primary tumor are transported by the peritoneal fluid or the circulatory system throughout the peritoneal cavity, which then "seed" the intraperitoneal surfaces from the diaphragm to the distal colon. Peritoneal spread may be quite extensive and surgical removal of peritoneal implants can lead to significant tissue disruption. Such cytoreductive surgeries have been suggested to facilitate the metastatic process [16-18,21]. Proposed mechanisms include: (1) surgical stress that reduces cell-mediated immunity and a concurrent pro-inflammatory response, (2) physical effects through the dissemination of more tumor cells into the circulating peritoneal fluid or blood, and (3) wound healing responses, such as inflammation, angiogenesis, and proliferation, triggered by the tissue trauma of surgery $[15,17,18]$. The accumulating evidence suggests that the post-surgical period is a favorable environment for the growth of new and existing microscopic residual disease.

\subsection{Exploiting the Peri-Operative Period to Improve Long-Term Ovarian Cancer Outcomes}

There is increasing evidence that many factors associated with surgical treatment of primary tumors modulate the tumor environment in a manner that can promote residual cancer survival and growth $[15,17,18]$. This critical time, the period just before surgery extending to several weeks following surgery, or the peri-operative period, is arguably a short time relative to the length of time for tumor growth and spread both before and after surgery. However, a number of studies have reported that drugs and physiological responses in this critical window can influence long-term outcomes such as recurrence and mortality. For example, inhalational anesthetics such as isoflurane or desflurane are associated with increased risk of death compared to propofol-based intravenous anesthesia based on a retrospective analysis of over 7,000 patients [18,22]. In contrast, peri-operative use of aspirin as an antithrombotic is associated with improved outcomes in patients with biliary, gastric, colorectal, 
or breast cancer $[18,23]$. Similarly, the beta-blocker propranolol decreased biomarkers of metastasis and modulated the immune environment in breast cancer [24,25]. Cyclooxygenase (COX) inhibitors have been largely studied for cancer chemoprevention [26-29], but new evidence suggests that women who used non-steroidal anti-inflammatory drugs (NSAIDs) after an ovarian cancer diagnosis had improved disease-specific survival compared with never-users [30,31]. These findings and others indicate that the anesthetic and analgesic type and approach used in and/or after surgery can influence cancer recurrence and metastasis $[15,17,18,32]$.

\subsection{Non-Steroidal Anti-Inflammatory Drugs (NSAIDs) and Cancer}

The benefit of NSAIDs as general chemopreventive and anti-cancer agents remains controversial due to mixed epidemiologic evidence [33-40]. The most compelling evidence linking anti-inflammation with survival is found in colorectal cancer (CRC), where aspirin use is associated with increased CRC survival (e.g., [41,42]). Understanding the effects of NSAIDs in cancer is hampered by differences in findings based on tumor type, limited knowledge on response stratification based on specific NSAID use, and lack of information on potential enantiomer-dependent pharmacologic activities of certain NSAIDs. Enantiomeric pairs may differ greatly in biologic response with profound birth defects due to the S-enantiomer of thalidomide serving as a dramatic example [43-45]. While many NSAIDs are developed only as the S-enantiomer, some NSAIDs, such as ketorolac, are administered as a 1:1 racemic mix of the R- and S-enantiomers with the S-forms having inhibitory activity toward COX enzymes [46-52]. Although the R-forms have negligible to no activity against COXs [46,48,49,53-56], there is mounting evidence that R-enantiomers are distinct chemical entities and precedence for pharmacologic activities dictated by R-enantiomers of specific NSAIDs against novel (non-COX) targets [57-64].

\section{Peri-Operative Use of Ketorolac}

Ketorolac was approved by the US Food and Drug Administration in 1989 as the first injectable NSAID [65]. Originally marketed as Toradol ${ }^{\circledR}$ (injection and tablet forms, Roche Laboratories, Nutley, New Jersey, USA), it is currently available as a generic drug. Ketorolac is non-narcotic but provides opioid-level pain management, thereby reducing narcotic requirements. In cancer, ketorolac may be used to control cancer-associated pain and is used as an analgesic during and after cancer surgeries [66-72].

\subsection{Peri-Operative Ketorolac and Breast Cancer Survival}

A 2010 breast cancer study [73] reported that among the 55\% of women who received ketorolac, there was a decreased risk of breast cancer relapse (Hazard Ratio (HR) $=0.4,95 \% \mathrm{CI}=0.1-0.8$ ) with a particular reduction in relapses in the first 24 months of follow-up [74,75]. However, other analgesics (sufentanil, ketamine, and clonidine) did not confer this benefit [73]. Subsequent analyses included either ketorolac or diclofenac (another NSAID), and exposure to either one was combined in the analyses [76]. In one breast center $(n=172$ patients), ketorolac/diclofenac was a strong predictor of recurrence-free survival (multivariate adjusted $\mathrm{HR}(\mathrm{aHR})=0.2,95 \% \mathrm{CI}=0.07-0.4)$ with recurrences reported in $6.9 \%$ of NSAID users at 60 months relative to $29.6 \%$ of non-users ( $p$-value $<0.001$ ). There were too few deaths for multivariate analyses, but mortality was $5.5 \%$ in users at 60 months relative to $20.7 \%$ in non-users ( $p$-value $<0.001)$. In another breast center $(\mathrm{n}=162$ patients) ketorolac users had half the recurrences $(3.0 \%)$ at 24 months versus non-users $(6.6 \%)$, but the differences were not significant. There were fewer deaths among ketorolac users (3.4\%) at 24 months than among non-users $(7.9 \%)$, but not significantly so. More recently, ketorolac was associated with decreased distant recurrences in breast cancer patients $(\mathrm{aHR}=0.59,95 \% \mathrm{CI}=0.37,0.96)$, perhaps driven by high-BMI patients ( $\mathrm{aHR}=0.55,95 \% \mathrm{CI}=0.31,0 / 96)$ [77]. While the evidence above suggests that ketorolac has an effect in clinical practice, the evidence is limited and is not specific to ovarian cancer. 
These studies also did not adjust for the propensity to receive ketorolac and had a limited ability to assess the more robust outcome of cancer-specific survival due to a short follow-up period.

\subsection{Peri-Operative Ketorolac and Ovarian Cancer}

We conducted an analysis of ovarian cancer survival as a function of peri-operative ketorolac administration [78]. Inclusion criteria for patients identified from the New Mexico Tumor Registry were: invasive, epithelial ovarian cancer, diagnosis age 40-79 years, diagnosis 2004-2006, and surgery at an Albuquerque hospital (only 3 hospitals provide this level of surgery). Diagnosis years were chosen so that each patient had at least 6 years follow-up through December 31, 2012. Medical records were abstracted for all analgesics and anesthesia used before hospital admission, during surgery and hospital stay, and given at discharge. Of 138 potential cases, eight had no surgery (palliative care only or died before surgery), one had surgery in another state, and medical records were not located for six, leaving 123 women in the final analysis. Peri-operative ketorolac was used in $14 \%$ of the women and was more likely to be received by younger women (versus older) $(p<0.05)$, other factors were not significantly different. At the 60-month follow-up, 3/17 ketorolac-treated (18\%) and $40 / 92$ non-treated patients $(43 \%)$ had died of ovarian cancer (log-rank test $p$-value $=0.09$ ). Stratified $\log$-rank tests for categorical factors such as age group, American Joint Committee on Cancer (AJCC) stage, completion of chemotherapy as planned, and receipt of neoadjuvant chemotherapy showed a consistent ketorolac survival benefit in each stratum [78]. The survival benefit of ketorolac was also evident in the proportional hazards analysis when adjusted for age at diagnosis, AJCC stage, completion of chemotherapy as planned, and receipt of neoadjuvant chemotherapy. The adjusted HR for ovarian cancer-specific mortality associated with peri-operative ketorolac (yes versus no) was 0.30 (95\% confidence interval (CI), 0.11-0.88). While these findings must be interpreted cautiously because they are only partially controlled for the propensity to receive ketorolac, they suggest that, similar to the breast cancer data, peri-operative ketorolac reduces ovarian cancer-specific mortality.

\subsection{Peri-Operative Ketorolac and Other Cancers (Non-Ovarian)}

In contrast to breast and ovarian cancer, in patients with prostate cancer there was no survival value for the intraoperative administration of ketorolac during prostatectomy $[79,80]$. In one study, no significant difference was found between general anesthesia plus post-operative ketorolac-morphine analgesia $(n=158)$ and general anesthesia plus intraoperative and post-operative thoracic epidural analgesia $(n=103)$ in biochemical recurrence-free survival, cancer-specific survival, or overall survival [80]. In another analysis of 1111 patients, the incidence of biochemical recurrence-free survival was compared in patients receiving epidural analgesia, intravenous ketorolac, sufentanil, clonidine, and ketamine in varying combinations. Sufentanil was associated with an increase in cancer relapse, but neither epidural analgesia nor other analgesics, including ketorolac, were associated with a statistically significant effect on biochemical recurrence-free survival $(p>0.05)$.

There are relatively few studies available for additional cancer types. However, the effects of ketorolac usage were studied in a group of non-small cell lung cancer (NSCLC) patients, and a group of kidney cancer patients who received major surgery [76]. Ketorolac administration was combined with diclofenac administration in some analyses, and the combined variable was referred to as "NSAID use". Of the 227 kidney patients, only 13 received ketorolac and 6 received diclofenac and they were not analyzed further. For NSCLC, there was a decrease in distant metastases (adjusted HR $=0.16$, $95 \% \mathrm{CI}=0.04,0.63$ ) and mortality (adjusted HR $=0.55,95 \% \mathrm{CI}=0.31,0.95$ ) with NSAID administration. For ketorolac alone, there was a significant decrease in mortality risk (adjusted $\mathrm{HR}=0.41,95 \% \mathrm{CI}=0.23$, $0.70, p<0.001$ ). A second study of 563 NSCLC patients [81] receiving an NSAID for postoperative pain management found that the majority of patients received ketorolac $(67 \%)$. Although celecoxib or ibuprofen administration was not predictive of overall survival, patients receiving ketorolac displayed better overall survival $(p=0.05)$ without differences in recurrence-free survival [81]. There are no clear answers for the lack of benefit with ketorolac administration in prostate cancer patients compared to 
other cancers, but collectively, the evidence supports further studies to determine whether ketorolac administration in the peri-operative window has the potential to improve patient outcomes.

\section{Dual Pharmacologic Actions of Ketorolac}

In the retrospective studies on ketorolac usage and cancer outcomes discussed above, patients received ketorolac in the peri-operative period. This raises the question of how a short duration, non-cytotoxic treatment can lead to durable survival benefit in cancer patients. As reviewed by Horowitz et al. [17] and Hiller et al. [18], the peri-operative period may promote metastatic disease in patients by a number of mechanisms, including (1) peri-operative factors such as psychological stress and mechanical stress associated with surgery and tumor excision, (2) increases in neuroendocrine and paracrine factors such as catecholamines and prostaglandins, (3) modulation of the immune system, and (4) modulation of angiogenic and growth factors. Together, these mechanisms may enhance the survival, implantation, and growth of residual tumor cells either directly or indirectly by modifying the tumor microenvironment. The authors assert that this convergence of events occurring during the short peri-operative window are critical to long-term cancer outcomes and may offer opportunities for interventions during the peri-operative period to improve patient outcomes.

\subsection{Cyclooxygenase (COX) Inhibition by S-ketorolac}

\subsubsection{COX Enzymes in Ovarian Cancer}

Prostaglandins are necessary for normal ovarian functions, such as ovulation, and are produced within the ovary [82]. In ovarian cancer, inflammation and downstream inflammatory mediators are associated with initiation and progression. This is believed to be through contributions to genomic instability via DNA damage by reactive oxygen species elevated at sites of inflammation and regulation of antiapoptotic pathways by cytokines and growth factors [82]. COX-1 and 2 are overexpressed in ovarian tumors [83-89] and correlate with worse features, such as angiogenesis and proliferation. COX enzymes catalyze the conversion of arachidonic acid into prostaglandin $\mathrm{H} 2$, which is the precursor for all prostaglandins and thromboxane A2. Prostaglandins and thromboxane are lipid signaling molecules that can promote cell proliferation, angiogenesis, metastasis, and inhibit apoptosis. Both COX enzymes are important in ovarian cancer but may be differentially expressed in less aggressive Type 1 and more aggressive Type 2 tumors [82,88]. Elevated COX-1 mRNA expression is associated with Type 2 tumors $[88,89]$ and Type 1 tumors are more likely to have high COX-2 mRNA levels [88]. Higher COX-1 mRNA expression was associated with shorter disease-free and overall survival, whereas COX-2 expression was associated with shorter disease-free survival amongst type 2 tumors [88]. Given the relationships between inflammation, aberrant COX expression and adverse consequences in ovarian cancer [82], COX inhibition by NSAIDs has been considered as a possible strategy to combat this disease.

NSAIDS are either COX-1 selective, COX-2 selective, or non-selective as inhibitors of COX enzymes. S-ketorolac is a potent and non-selective COX inhibitor with somewhat lower half-maximal inhibitory concentration $\left(\mathrm{IC}_{50}\right.$ ) values for COX-1 than COX-2 in purified enzyme assays [63]. Ketorolac is significantly more potent than the non-selective COX inhibitors indomethacin or diclofenac in in vivo analyses of NSAID function for alleviation of pain and inflammation [53]. These functional outcomes are due to COX inhibition and attributed to the S-enantiomer as the R-enantiomer is more than 100 times less potent for inhibition of either COX enzyme [52,56,63,65]. Additional studies will be needed to discern whether COX selectivity of an NSAID is an important factor in cancer risk or tumor response.

\subsubsection{COX Inhibitors and Ovarian Cancer Outcomes}

The vast majority of published studies on NSAIDs and ovarian cancer outcomes are focused on the risk of developing ovarian cancer rather than peri-operative use. A number of reports conclude 
that NSAID use reduces ovarian cancer risk, but findings differ between studies [29,30,34,90-97]. Low dose aspirin appears to be protective $[30,90,93,96,97]$ and a recent study suggested that long-term, high-quantity use of non-aspirin NSAIDs is associated with increased ovarian cancer risk, although the authors state that the finding requires confirmation [96]. Other studies find that any NSAID decreases risk [94], but there appears to be a greater advantage to aspirin use [93]. A large observational study of pooled individual data for 7694 women across multiple studies and self-reported regular use of NSAIDs before ovarian cancer diagnosis did not find an association with survival (disease-free or overall) [95]. However, the authors noted that when they restricted the analyses to the subset of studies with clear definition of NSAID use or non-use (non-use as less than once per week), a survival benefit was detected with use of any NSAIDs [95]. The authors also noted that improved and consistent definitions for NSAID use before and after diagnosis is needed [95] to help resolve the differences in reported study results.

Randomized clinical trials of ketorolac in cancer have provided comparison in efficacy of pain relief rather than insights into patient survival outcomes. However, in one randomized clinical trial, the NSAID celecoxib was investigated by adding it to chemotherapy (docetaxel plus carboplatin) because elevated COX-2 protein expression is detected in ovarian cancer patients [85-87] and the transcription of COX-2 can be stimulated by taxanes (standard chemotherapy for ovarian cancer patients) $[98,99]$. Unfortunately, celecoxib with chemotherapy did not improve survival and $24 \%$ of women discontinued celecoxib due to side effects [99].

There is limited information on NSAID use after ovarian cancer diagnosis, but one recent study reported intriguing results. Reported NSAID use pre-diagnosis was not positively associated with ovarian cancer-specific survival. However, women who reported recent (current use in the past 2 years) use of aspirin or non-aspirin NSAIDs after diagnosis had improved ovarian cancer-specific survival compared with never-users [30]. This survival benefit was not found for post-diagnosis use of paracetamol (acetaminophen), suggesting that COX inhibitors may not be equivalent for survival outcomes. This study highlights the need for additional research on post-diagnosis use of NSAIDs and patient outcomes to supplement the studies on ovarian cancer risk. Although the mechanisms contributing to the observed benefits of NSAID use after diagnosis are not known, experimental studies suggest that tumor debris from chemotherapy stimulates proinflammatory cytokines and bioactive lipids, thereby stimulating tumor growth through numerous signaling pathways. A dual COX-2/soluble epoxide hydrolase inhibitor (PTUPB) markedly enhanced survival and delayed the onset of a debris-stimulated increase in inflammatory mediators in experimental models [100]. This finding suggests that multi-target strategies in the peri- or post-operative period may provide greater benefits than COX inhibition alone.

\subsection{Rac1 and Cdc42 Inhibition by R-ketorolac}

\subsubsection{Rac1 and Cdc42 GTPases in Ovarian Cancer}

Rac1 and Cdc42 are regulators of numerous functions related to tumor development, progression, metastasis, and chemo-resistance [101-109]. Rac1 activity and expression are frequently elevated in tumors and a recent meta-analysis of 1,793 patients in 14 studies concluded that Rac1 expression was a poor prognostic indicator across cancers [110]. Our analysis of the 298 Stage III and IV high-grade serous ovarian cancer (HGSOC) patients with outcomes data in The Cancer Genome Atlas (TCGA) demonstrate that high total RAC1 (but not CDC42) mRNA expression is associated with worse outcomes [105]. This finding concurs with another analysis of Rac1 as a prognostic factor in a cohort of 150 ovarian cancer patients [111].

\subsubsection{Identification of R-Ketorolac as a Rac1 and Cdc42 Inhibitor}

Rac1 inhibitors have anti-tumor benefits in multiple cell and animal models of cancer, leading to vigorous efforts to identify clinically useful agents, reviewed in $[108,109,112-116]$. Based on a 
high-throughput screen of 8 Ras-related small GTPases against off patent, FDA-approved drugs and cheminformatics, we identified the R-enantiomer of ketorolac as a selective inhibitor of Rac1 and Cdc42 with no activity against the related GTPase RhoA [63]. The S-enantiomer was inactive against these GTPase targets $[63,64]$ and R-ketorolac was inactive against COX enzymes. Although it has been long recognized that R-enantiomers of NSAIDs are poor inhibitors of cyclooxygenase activity $[46,48,49,53-56]$, relatively little is known about potential pharmacologic activities or targets for these R-enantiomers.

R-ketorolac is a noncompetitive inhibitor of Rac1 and Cdc42 with $\mathrm{IC}_{50}$ values of 0.57 and $1.07 \mu \mathrm{M}$, respectively [64]. Although a limited number of additional candidates were identified in the high-throughput screen, including R-naproxen, S-ibuprofen, and sulindac sulfide, more than 20 other NSAIDs are inactive against these proteins, confirming that the interaction with Rac1 and Cdc42 was not a general property of this class of drugs [63]. R-ketorolac inhibits serum and EGF-stimulated Rac1 and Cdc42 activation and downstream signaling through a proposed allosteric mechanism. Thus, identification of a novel activity for R-ketorolac has precedence in the literature and further indicates that R-enantiomers are distinct chemical entities compared to the corresponding S-forms [47,57-62].

\subsubsection{Experimental Evidence for Benefits of Rac1 Inhibition in Ovarian Cancer}

Rac1 is a driver of numerous cancer-relevant phenotypes associated with worse patient outcomes. The broad impact of Rac1 on tumor cell behavior has led to consideration of Rac1 as a potential therapeutic target [102,108,112-116]. In ovarian cancer cell lines, knock down of Rac1 expression reversed epithelial to mesenchymal transition (EMT) [111,117], inhibited tumor cell migration and invasion [111], and reduced tumor growth in a xenograft model [111]. An inhibitor of Rac1 (NSC23766) decreased ovarian tumor cell migration, invasion, and matrix-metalloproteinase production $[63,64,118]$.

We find that R-ketorolac and R-naproxen inhibit tumor cell adhesion, migration, and invasion -all behaviors that are central to ovarian cancer metastasis [63,64]. R-ketorolac was tested using ovarian tumor cell lines and primary ovarian tumor cells isolated from patient ascites fluids [64]. R-ketorolac was an effective Rac1 inhibitor and decreased downstream signaling, as demonstrated by reduction of PAK1 and PAK2 phosphorylation [78]. R-ketorolac, but not S-ketorolac, inhibited Rac1-dependent cellular functions in ovarian cancer cell lines and primary cells including inhibition of growth factor-stimulated formation of filopodia, cell adhesion to fibronectin and type I collagen, development of invadopodia, and tumor cell migration [64]. The inhibitory effects of R-ketorolac and R-naproxen in cells are comparable to those of established Rac1 and Cdc42 selective inhibitors [64,119]. R-ketorolac [120] and R-naproxen (Figure 1) also inhibit ovarian tumor cell omental engraftment and tumor growth in vivo, with little impact of the S-enantiomers or an achiral metabolite, 6-methoxy-2-naphthylacetic acid (6MNA).

Furthermore, R-ketorolac treatment led to increased survival of mice in a xenograft study using OVCAR8 ovarian cancer cells (Figure 2). These preclinical findings suggest that R-ketorolac may have beneficial actions in human ovarian cancer that could account for improved patient outcomes associated with peri-operative ketorolac use. 

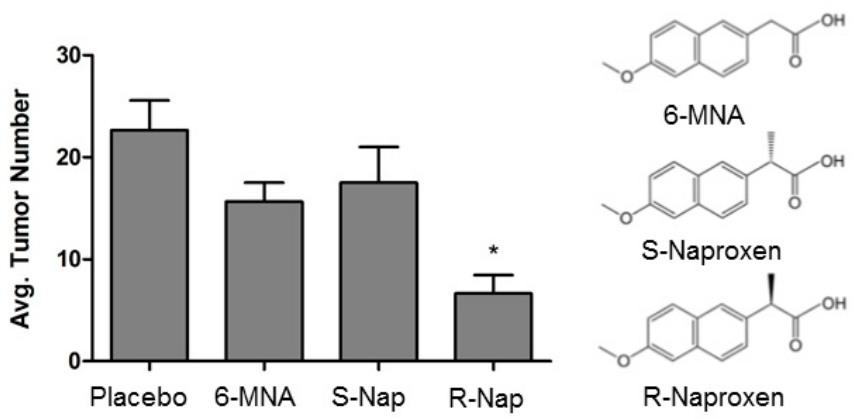

Figure 1. R-Naproxen reduces ovarian tumor peritoneal implants in a xenograft model. One day prior to intraperitoneal injection of green fluorescent protein (GFP)-tagged SKOV3ip cells into athymic nude mice, mice were administered placebo or the indicated treatments to approximate serum levels equivalent to human dosing. Drug was administered daily for 2 weeks. At this time, mice were sacrificed, and images of the peritoneal cavity were obtained. All tumors were counted and aided by GFP imaging. ${ }^{*} p<-0.05 \mathrm{C}=$ placebo; 6-MNA = 6-methoxy-2-naphthylacetic acid; S-Nap = S-naproxen; $\mathrm{R}-\mathrm{Nap}=\mathrm{R}$-naproxen. 6-MNA is the active metabolite of the non-racemic NSAID nabumetone and is structurally similar to R-naproxen but lacks the alpha-methyl carboxylate ( $\alpha$-Me-COOH) determined to be essential for activity [63].

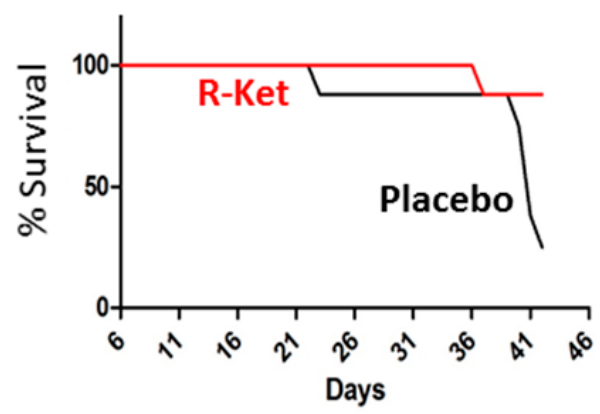

Figure 2. R-ketorolac improves survival in an in vivo xenograft model of ovarian cancer. OVCAR8 xenografts were established, then mice were treated with $10 \mathrm{mg} / \mathrm{kg} /$ day R-ketorolac or placebo by intraperitoneal injection for 6 weeks. The R-ketorolac group (R-Ket, red line) displayed improved survival compared to the placebo (black line) group ( $88 \%$ survival versus $25 \%$ survival). One mouse in the R-ketorolac group was lost at 37 days of treatment. For the placebo control group, mice were lost at day 23 (1), day 40 (1), day 41 (3), and day 42 (1, study termination). There was a statistically significant difference ( $p$-value $\leq 0.0142$ ) in survival between the placebo and R-ketorolac treatment groups, as determined using the Kaplan-Meier method and comparisons using the log-rank test. $N=8$ mice/group.

\section{Is There Potential for Ketorolac in Ovarian Cancer Management?}

Racemic ketorolac is orally bioavailable and has been commercialized as topical (ocular, intranasal), injectable (intravenous or intramuscular), and oral formulations. This makes ketorolac an ideal candidate for human clinical trials. However, ketorolac has limitations as well. Ketorolac is contraindicated in patients with peptic ulcer disease, gastrointestinal bleeding, or advanced renal impairment, a common clinical issue in elderly women with ovarian cancer [65]. Use is restricted to a 5-day treatment course that could limit application for extended post-operative care in cancer patients. Within these limitations, we designed and conducted a "Phase 0 " clinical trial. Ovarian cancer patients received racemic ketorolac for its FDA-approved indication in post-operative analgesia [78], then blood and peritoneal fluids were collected at intervals for $24 \mathrm{~h}$. Ketorolac was distributed to the peritoneum within 1 hour after IV administration, and at $6 \mathrm{~h}$, ketorolac levels in the peritoneal fluids were nearly equivalent to those present in the serum. At each of the time points (1, 6, and $24 \mathrm{~h})$ after administration of the racemic drug, peritoneal fluids were enriched in R-ketorolac compared to the 
S-enantiomer. R-ketorolac achieved concentrations in the peritoneal fluids at or above the $\mathrm{IC}_{50}$ values for Rac1 and Cdc42 and was therefore predicted to inhibit these GTPase targets in cells obtained from this compartment. This prediction was supported by the finding of time-dependent inhibition of Rac1 and Cdc42 activity in cells retrieved from the peritoneal compartment of these post-surgical ovarian cancer patients after ketorolac administration [78]. Because R-ketorolac predominates in the peritoneal fluids and the S-enantiomer is virtually undetectable at $24 \mathrm{~h}$, this indicates that the R-enantiomer is bioactive and accounts for the observed inhibition of the GTPases in vivo.

To better understand the potential consequences of ketorolac treatment, we conducted gene expression analysis by RNA-sequencing of human ovarian cancer xenografts following ketorolac treatment. Mice were treated with a human equivalent dose of racemic ketorolac $(1 \mathrm{mg} / \mathrm{kg} /$ day $)$ for two weeks. A list of 53 significantly differentially expressed genes was generated from the RNA-sequencing analysis. Of 53 differentially expressed genes, 51 were downregulated by R-ketorolac. Enrichment analysis indicated that these genes affect several important biological functions. Using topGO to probe the Gene Ontologies (GO) database, we found the gene list to be enriched in 20 biological processes including 34 genes mainly involved in cellular development process, vasculature development, and response to hypoxia (Figure 3). We further analyzed the differentially significant genes by using Pathview [121,122] and DAVID [123,124] to probe the Kyoto Encyclopedia of Genes and Genomes (KEGG) to see if ketorolac had an effect on specific pathways. KEGG pathway analysis demonstrated that the down-regulated, differentially expressed genes were enriched in three significant pathways, including the HIF-1 signaling pathway ( $p$-value $\left.6.3^{-06}\right)$, the PI3K-AKT signaling pathway $\left(1.6^{-02}\right)$, and the Focal Adhesion pathway $\left(2 \cdot 1^{-02}\right)$.

\section{Gene Set Enrichment Analysis}

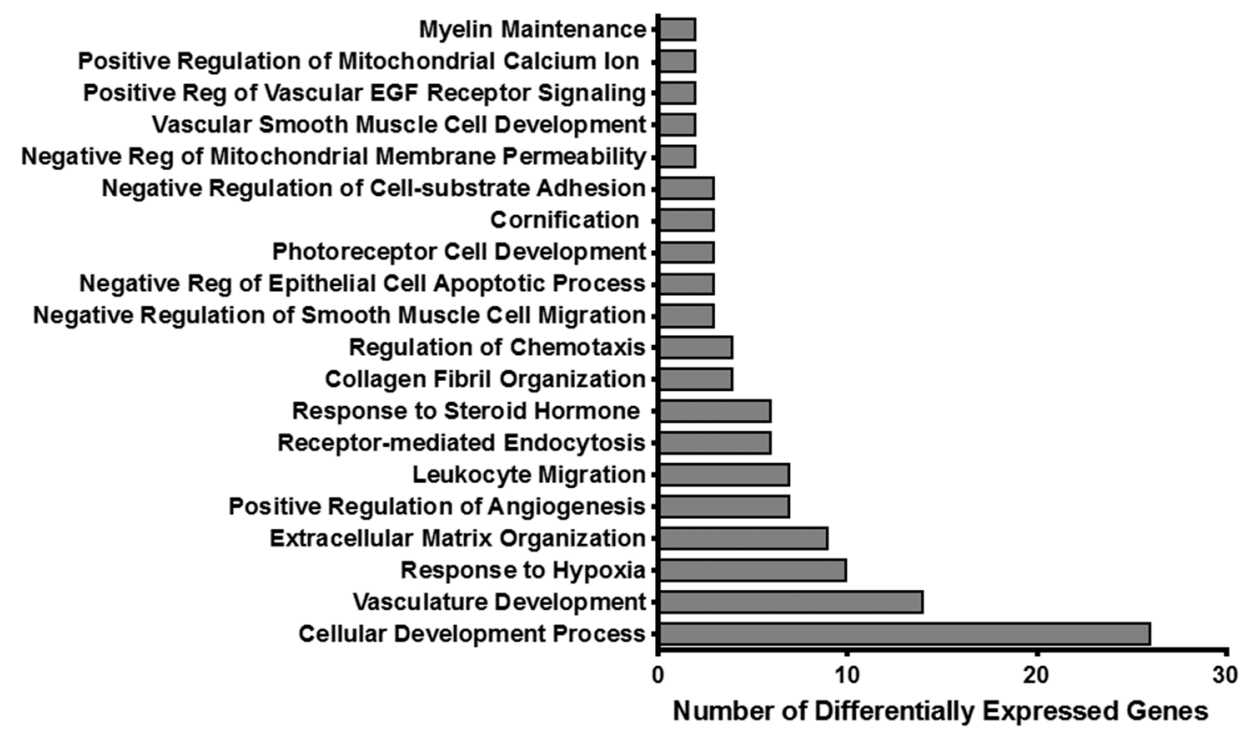

Figure 3. Ketorolac treatment down-regulates gene expression signatures in a mouse xenograft model of ovarian cancer. SKOV3ip xenografts were established, then mice were treated with racemic ketorolac at $1 \mathrm{mg} / \mathrm{kg} / \mathrm{day}$ oral dosing or placebo for two weeks. Rac1 and Cdc42 activity was decreased by approximately $50 \%$ and $35 \%$ respectively, similar to what we found in clinical samples [78]. RNA-sequencing was conducted on tumors isolated from mice. Differentially expressed genes were identified using a threshold of $>2$-fold change and a false discovery adjusted $p$-value cut-off of 0.05 . All genes in this set were down-regulated by ketorolac.

A limitation for applying findings from the mouse xenograft study to humans is based on the enantiomer-selective pharmacokinetics of ketorolac. There is greater retention of R-ketorolac compared to S-ketorolac after administration of racemic drug in mice and humans [56,78]. R-ketorolac is not significantly converted to S-ketorolac in mice or humans, but S-ketorolac is significantly converted 
to the R-enantiomer in mice, further favoring the ratio of R- to S-ketorolac [56]. Because humans do not convert S-ketorolac to R-ketorolac [56], the mouse studies reflect a greater proportion of $\mathrm{R}$-ketorolac after administration of the racemic drug than might be true for humans after repeated doses. However, our findings support the conclusion that both the S- and the R-enantiomers of ketorolac are pharmacologically active in patients, and both the COX inhibitory, as well as the Rac1/Cdc42 inhibitory activities, should be taken into account when interpreting findings obtained after administration of the FDA-approved racemic drug.

\section{Conclusions}

The anti-cancer-relevant actions of R-ketorolac are evident in experimental models $[63,64,120]$. Based on the predominance of R-ketorolac over S-ketorolac in blood and peritoneal fluids, coupled with GTPase target inhibition after administration of racemic drug [78], we can infer that R-ketorolac is active as a Rac1/Cdc42 inhibitor in humans. Although Rac1/Cdc42 are recognized as attractive therapeutic targets in cancer, no selective inhibitors have advanced to human use. Our clinical study indicates that Rac1/Cdc42 inhibition can be achieved in humans at currently approved doses of the racemic drug.

At this time, it is not known whether a subset of patients overexpressing Rac1 would be more likely to benefit from ketorolac. Indeed, elevated mRNA expression may not be the best determinant of tumor Rac1 activity for two major reasons. First, as an integrator of upstream signals generated by receptor tyrosine kinases, G-protein-coupled receptors, integrins, and other adhesion molecules, Rac1 activity varies based on factors within the tumor microenvironment $[103,105,107]$. Secondly, the activity of Rac1 is tightly controlled by a large network of modulatory proteins (e.g., Guanine nucleotide exchange factors, GEFs and GTPase activating proteins, GAPs) that have profound effects on net Rac1 activity and elevated activity would not be evident based on Rac1 mRNA or protein expression alone [103,105,107]. As one example, ARHGAP5 is a protein that stimulates GTP hydrolysis on Rac1 and the related family member RhoA (Ras homolog gene family, member A) resulting in decreased activation of these GTPases. The rs 927062 variant of ARHGAP5 was found to be associated with increased endometrioid and invasive serious ovarian cancer risk [125] and a statistically significant decrease of ARHGAP5 protein which would be predicted to increase Rac1 and RhoA activity. It will be important to resolve the question of whether patients with elevated Rac1 expression and/or activity are most likely to benefit from ketorolac and if so, what markers would be appropriate for patient stratification.

Studies suggest that the anti-inflammatory actions of NSAIDs in ovarian cancer may confer benefits, but it is clear that additional research on the timing of NSAID use, whether pre-diagnosis, peri-operative, or post-diagnosis, is needed. Similarly, there is evidence that NSAIDs may not be equivalent in anti-cancer activity and more work will be required to discern the distinctions of specific NSAID use within the different timing contexts.

A recent study tested pre-operative administration of ketorolac versus other NSAIDs in mouse models of cancer [126]. Ketorolac dosing before, but not after, resection of the subcutaneous tumors led to decreased metastatic recurrence and increased survival. Several other NSAIDs tested (indomethacin, aspirin, ibuprofen, diclofenac, celecoxib) were inactive or substantially less active than ketorolac for survival outcomes, although three highly selective COX-1 inhibitors displayed benefit similar in magnitude to ketorolac [126]. Modifications of ketorolac may improve efficacy compared to the parent drug. A 1,2,3-triazolyl ester of ketorolac called "15K" was synthesized and found to be substantially more potent than ketorolac for PAK and COX-2 inhibition, and cytotoxicity against lung and melanoma cancer cell lines [127]. In addition, this compound inhibited embryonic angiogenesis in a chorioallantoic membrane assay [128]. These and future experimental studies are critical for resolving key questions on the benefits of specific NSAIDs, including ketorolac or future derivatives, in cancer patients.

Taken together, our identification of R-ketorolac as a Rac1/Cdc42 GTPase inhibitor may help to explain the apparent benefits of racemic ketorolac in human breast and ovarian cancer patient survival, and why other NSAIDs have not yielded comparable findings. The current status of the literature 
indicates that both classes of targets (COXs and Rac1/Cdc42 GTPases) are important in ovarian cancer progression, metastasis, and patient outcome. Clinical trials using R-ketorolac alone would offer an opportunity to directly test the predicted benefit of a Rac1/Cdc42-selective inhibitor in ovarian cancer patients. R-ketorolac could circumvent current renal and hematologic toxicities that restrict the use of racemic ketorolac to five days [65] and enhance the duration of R-ketorolac administration for peri-operative or post-operative therapy. Studies focused on R-ketorolac would also help resolve the question of whether reported survival benefits are due to the unexpected and potentially fortuitous dual pharmacologic activities in the approved racemic drug.

\section{Patents}

“Modulators of GTPases and Their Use (NSAIDs)" Inventors: Angela Wandinger-Ness, Larry A. Sklar, Tudor I. Oprea, Laurie Hudson and Zurab Surviladze. United States Patent and Trademark Office award 9,125,899. September 8, 2015.

Author Contributions: Contributions are as follows: conceptualization, L.G.H., L.S.C., C.Y.M. and A.W.-N.; writing-original draft preparation, L.G.H. and L.S.C.; writing-review and editing, L.G.H., L.S.C., M.M.G., C.Y.M., S.F.A., A.W.-N.

Funding: This research was funded by the National Institutes of Health, grant NCATS R21 TR001731to L.G.H. and A.W.-N.; P50 GM085273 Project 3 to A.W.-N.; NCI Cancer Center P30CA118100 pilot funding to L.S.C and post-doc matching grant to M.M.G.

Acknowledgments: Some experiments used the facilities or services provided by the Analytical and Translational Genomics (ATG) Shared Resource and the Biostatistics Shared Resource (BSR), facilities supported by the State of New Mexico and the UNM Cancer Center P30CA118100. We would like to acknowledge and thank Erin Trachet of MI Bioresearch for providing OVCAR8 survival data with permission from Revere Pharmaceuticals.

Conflicts of Interest: The authors declare no conflict of interest. The funders had no role in the design of the study, in the collection, analyses, or interpretation of data, in the writing of the manuscript, or in the decision to publish the results.

\section{References}

1. SEER*Explorer: An Interactive Website for SEER Cancer Statistics. Surveillance Research Program, National Cancer Institute. Available online: https://seer.cancer.gov/explorer/index.html (accessed on 23 June 2019).

2. Bast, R.C.; Matulonis, U.A.; Sood, A.K.; Ahmed, A.A.; Amobi, A.E.; Balkwill, F.R.; Wielgos-Bonvallet, M.; Bowtell, D.D.L.; Brenton, J.D.; Brugge, J.S.; et al. Critical questions in ovarian cancer research and treatment: Report of an American Association for Cancer Research Special Conference. Cancer 2019, 125, 1963-1972. [CrossRef] [PubMed]

3. Narod, S. Can advanced-stage ovarian cancer be cured? Nat. Rev. Clin. Oncol. 2016, 13, 255-261. [CrossRef] [PubMed]

4. Bowtell, D.D.; Böhm, S.; Ahmed, A.A.; Aspuria, P.-J.; Bast, R.C., Jr.; Beral, V.; Berek, J.S.; Birrer, M.J.; Blagden, S.; Bookman, M.A.; et al. Rethinking ovarian cancer II: Reducing mortality from high-grade serous ovarian cancer. Nat. Rev. Cancer 2015, 15, 668-679. [CrossRef] [PubMed]

5. Garces, Á.H.I.; Dias, M.S.F.; Paulino, E.; Ferreira, C.G.M.; de Melo, A.C. Treatment of ovarian cancer beyond chemotherapy: Are we hitting the target? Cancer Chemother. Pharmacol. 2015, 75, 221-234. [CrossRef] [PubMed]

6. Ottevanger, P.B. Ovarian cancer stem cells more questions than answers. Semin. Cancer Biol. 2017, 44, 67-71. [CrossRef] [PubMed]

7. Matsumoto, K.; Onda, T.; Yaegashi, N. Pharmacotherapy for recurrent ovarian cancer: Current status and future perspectives. Jpn. J. Clin. Oncol. 2015, 45, 408-410. [CrossRef]

8. Nwani, N.G.; Sima, L.E.; Nieves-Neira, W.; Matei, D. Targeting the Microenvironment in High Grade Serous Ovarian Cancer. Cancers 2018, 10, 266. [CrossRef] [PubMed]

9. Chan, J.K.; Chow, S.; Bhowmik, S.; Mann, A.; Kapp, D.S.; Coleman, R.L. Metastatic gynecologic malignancies: Advances in treatment and management. Clin. Exp. Metastasis 2018, 35, 521-533. [CrossRef]

10. DiSilvestro, P.; Secord, A.A. Maintenance treatment of recurrent ovarian cancer: Is it ready for prime time? Cancer Treat. Rev. 2018, 69, 53-65. [CrossRef] 
11. Moore, K.; Colombo, N.; Scambia, G.; Kim, B.-G.; Oaknin, A.; Friedlander, M.; Lisyanskaya, A.; Floquet, A.; Leary, A.; Sonke, G.S.; et al. Maintenance Olaparib in Patients with Newly Diagnosed Advanced Ovarian Cancer. N. Engl. J. Med. 2018, 379, 2495-2505. [CrossRef]

12. Yap, T.A.; Carden, C.P.; Kaye, S.B. Beyond chemotherapy: Targeted therapies in ovarian cancer. Nat. Rev. Cancer 2009, 9, 167-181. [CrossRef] [PubMed]

13. Kim, R. Effects of surgery and anesthetic choice on immunosuppression and cancer recurrence. J. Transl. Med. 2018, 16, 8. [CrossRef] [PubMed]

14. Pantziarka, P.; Bouche, G. Perioperative Therapies-Using Repurposed Drugs to Improve Cancer Surgery Outcomes. Cancer J. 2019, 25, 100-105. [CrossRef] [PubMed]

15. Pantziarka, P.; Bouche, G.; Sullivan, R.; Ilbawi, A.M.; Dare, A.J.; Meheus, L. Perioperative therapies-Enhancing the impact of cancer surgery with repurposed drugs. Eur. J. Surg. Oncol. 2017, 43, 1985-1988. [CrossRef] [PubMed]

16. Tohme, S.; Simmons, R.L.; Tsung, A. Surgery for Cancer: A Trigger for Metastases. Cancer Res. 2017, 77, 1548-1552. [CrossRef] [PubMed]

17. Horowitz, M.; Neeman, E.; Sharon, E.; Ben-Eliyahu, S. Exploiting the critical perioperative period to improve long-term cancer outcomes. Nat. Rev. Clin. Oncol. 2015, 12, 213-226. [CrossRef] [PubMed]

18. Hiller, J.G.; Perry, N.J.; Poulogiannis, G.; Riedel, B.; Sloan, E.K. Perioperative events influence cancer recurrence risk after surgery. Nat. Rev. Clin. Oncol. 2018, 15, 205-218. [CrossRef] [PubMed]

19. Tan, D.S.; Agarwal, R.; Kaye, S.B. Mechanisms of transcoelomic metastasis in ovarian cancer. Lancet Oncol. 2006, 7, 925-934. [CrossRef]

20. Yeung, T.-L.; Leung, C.S.; Yip, K.-P.; Au Yeung, C.L.; Wong, S.T.C.; Mok, S.C. Cellular and molecular processes in ovarian cancer metastasis. A Review in the Theme: Cell and Molecular Processes in Cancer Metastasis. Am. J. Physiol. Cell Physiol. 2015, 309, C444-C456. [CrossRef]

21. Demicheli, R.; Retsky, M.W.; Hrushesky, W.J.M.; Baum, M.; Gukas, I.D. The effects of surgery on tumor growth: A century of investigations. Ann. Oncol. 2008, 19, 1821-1828. [CrossRef]

22. Wigmore, T.J.; Mohammed, K.; Jhanji, S. Long-Term Survival for Patients Undergoing Volatile versus IV Anesthesia for Cancer SurgeryA Retrospective Analysis. Anesthesiol. J. Am. Soc. Anesthesiol. 2016, 124, 69-79.

23. Algra, A.M.; Rothwell, P.M. Effects of regular aspirin on long-term cancer incidence and metastasis: A systematic comparison of evidence from observational studies versus randomised trials. Lancet Oncol. 2012, 13, 518-527. [CrossRef]

24. Zhou, L.; Li, Y.; Li, X.; Chen, G.; Liang, H.; Wu, Y.; Tong, J.; Ouyang, W. Propranolol Attenuates Surgical Stress-Induced Elevation of the Regulatory T Cell Response in Patients Undergoing Radical Mastectomy. J. Immunol. 2016, 196, 3460-3469. [CrossRef] [PubMed]

25. Shaashua, L.; Shabat-Simon, M.; Haldar, R.; Matzner, P.; Zmora, O.; Shabtai, M.; Sharon, E.; Allweis, T.; Barshack, I.; Hayman, L.; et al. Perioperative COX-2 and $\beta$-Adrenergic Blockade Improves Metastatic Biomarkers in Breast Cancer Patients in a Phase-II Randomized Trial. Clin. Cancer Res. 2017, 23, 4651-4661. [CrossRef] [PubMed]

26. Cuzick, J. Preventive therapy for cancer. Lancet Oncol. 2017, 18, e472-e482. [CrossRef]

27. Singh Ranger, G. The role of aspirin in colorectal cancer chemoprevention. Crit. Rev. Oncol./Hematol. 2016, 104, 87-90. [CrossRef] [PubMed]

28. Crusz, S.M.; Balkwill, F.R. Inflammation and cancer: Advances and new agents. Nat. Rev. Clin. Oncol. 2015, 12, 584-596. [CrossRef]

29. Ni, X.; Ma, J.; Zhao, Y.; Wang, Y.; Wang, S. Meta-analysis on the association between non-steroidal anti-inflammatory drug use and ovarian cancer. Br. J. Clin. Pharmacol. 2013, 75, 26-35. [CrossRef]

30. Merritt, M.A.; Rice, M.S.; Barnard, M.E.; Hankinson, S.E.; Matulonis, U.A.; Poole, E.M.; Tworoger, S.S. Pre-diagnosis and post-diagnosis use of common analgesics and ovarian cancer prognosis (NHS/NHSII): A cohort study. Lancet Oncol. 2018, 19, 1107-1116. [CrossRef]

31. Webb, P.M. Does aspirin have a role in management of ovarian cancer? Lancet Oncol. 2018, 19, 1011-1012. [CrossRef]

32. Heaney, A.; Buggy, D.J. Can anaesthetic and analgesic techniques affect cancer recurrence or metastasis? Br. J. Anaesth. 2012, 109 (Suppl. 1), i17-i28. [CrossRef]

33. Zhang, L.; Liu, W.; Wang, X.; Wang, X.; Sun, H. Prognostic value of serum IL-8 and IL-10 in patients with ovarian cancer undergoing chemotherapy. Oncol. Lett. 2019, 17, 2365-2369. [CrossRef] [PubMed] 
34. Murphy, M.A.; Trabert, B.; Yang, H.P.; Park, Y.; Brinton, L.A.; Hartge, P.; Sherman, M.E.; Hollenbeck, A.; Wentzensen, N. Non-steroidal anti-inflammatory drug use and ovarian cancer risk: Findings from the NIH-AARP Diet and Health Study and systematic review. Cancer Causes Control 2012, 23, 1839-1852. [CrossRef] [PubMed]

35. Frouws, M.A.; van Herk-Sukel, M.P.P.; Maas, H.A.; de Velde, C.J.H.V.; Portielje, J.E.A.; Liefers, G.-J.; Bastiaannet, E. The mortality reducing effect of aspirin in colorectal cancer patients: Interpreting the evidence. Cancer Treat. Rev. 2017, 55, 120-127. [CrossRef] [PubMed]

36. Dulai, P.S.; Singh, S.; Marquez, E.; Khera, R.; Prokop, L.J.; Limburg, P.J.; Gupta, S.; Murad, M.H. Chemoprevention of colorectal cancer in individuals with previous colorectal neoplasia: Systematic review and network meta-analysis. BMJ 2016, 355. [CrossRef]

37. Verdoodt, F.; Friis, S.; Dehlendorff, C.; Albieri, V.; Kjaer, S.K. Non-steroidal anti-inflammatory drug use and risk of endometrial cancer: A systematic review and meta-analysis of observational studies. Gynecol. Oncol. 2016, 140, 352-358. [CrossRef] [PubMed]

38. Wilson, J.C.; Anderson, L.A.; Murray, L.J.; Hughes, C.M. Non-steroidal anti-inflammatory drug and aspirin use and the risk of head and neck cancer: A systematic review. Cancer Causes Control 2011, 22, 803-810. [CrossRef]

39. Thorat, M.A.; Cuzick, J. Role of Aspirin in Cancer Prevention. Curr. Oncol. Rep. 2013, 15, 533-540. [CrossRef]

40. Sahin, I.H.; Hassan, M.M.; Garrett, C.R. Impact of non-steroidal anti-inflammatory drugs on gastrointestinal cancers: Current state-of-the science. Cancer Lett. 2014, 345, 249-257. [CrossRef]

41. Chan, A.T.; Ogino, S.; Fuchs, C.S. Aspirin Use and Survival After Diagnosis of Colorectal Cancer. JAMA 2009, 302, 649-658. [CrossRef]

42. Rothwell, P.M.; Wilson, M.; Elwin, C.-E.; Norrving, B.; Algra, A.; Warlow, C.P.; Meade, T.W. Long-term effect of aspirin on colorectal cancer incidence and mortality: 20-year follow-up of five randomised trials. Lancet 2010, 376, 1741-1750. [CrossRef]

43. Ariëns, E.J. Stereochemistry, a basis for sophisticated nonsense in pharmacokinetics and clinical pharmacology. Eur. J. Clin. Pharmacol. 1984, 26, 663-668. [CrossRef] [PubMed]

44. Smith, S.W. Chiral toxicology: it's the same thing ... only different. Toxicol. Sci. 2009, 110, 4-30. [CrossRef] [PubMed]

45. Vargesson, N. Thalidomide-induced teratogenesis: History and mechanisms. Birth Defects Res. Part C Embryo Today Rew. 2015, 105, 140-156. [CrossRef] [PubMed]

46. Hayball, P.J. Chirality and nonsteroidal anti-inflammatory drugs. Drugs 1996, 52 (Suppl. 5), 47-58. [CrossRef]

47. Wechter, W.J. Drug chirality: On the mechanism of R-aryl propionic acid class NSAIDs. Epimerization in humans and the clinical implications for the use of racemates. J. Clin. Pharmacol. 1994, 34, 1036-1042. [CrossRef] [PubMed]

48. Evans, A.M. Enantioselective pharmacodynamics and pharmacokinetics of chiral non-steroidal anti-inflammatory drugs. Eur. J. Clin. Pharmacol. 1992, 42, 237-256. [CrossRef]

49. Carabaza, A.; Cabré, F.; Rotllan, E.; Gómez, M.; Gutiérrez, M.; García, M.L.; Mauleón, D. Stereoselective Inhibition of Inducible Cyclooxygenase by Chiral Nonsteroidal Antiinflammatory Drugs. J. Clin. Pharmacol. 1996, 36, 505-512. [CrossRef]

50. Duggan, K.C.; Walters, M.J.; Musee, J.; Harp, J.M.; Kiefer, J.R.; Oates, J.A.; Marnett, L.J. Molecular Basis for Cyclooxygenase Inhibition by the Non-Steroidal Anti-Inflammatory Drug Naproxen. J. Biol. Chem. 2010, 285, 34950-34959. [CrossRef]

51. Harman, C.A.; Turman, M.V.; Kozak, K.R.; Marnett, L.J.; Smith, W.L.; Garavito, R.M. Structural Basis of Enantioselective Inhibition of Cyclooxygenase-1 by S- $\alpha$-Substituted Indomethacin Ethanolamides. J. Biol. Chem. 2007, 282, 28096-28105. [CrossRef]

52. Handley, D.A.; Cervoni, P.; McCray, J.E.; McCullough, J.R. Preclinical Enantioselective Pharmacology of (R)and (S)-Ketorolac. J. Clin. Pharmacol. 1998, 38, 25S-35S. [CrossRef] [PubMed]

53. Jett, M.-F.; Ramesha, C.S.; Brown, C.D.; Chiu, S.; Emmett, C.; Voronin, T.; Sun, T.; O’Yang, C.; Hunter, J.C.; Eglen, R.M.; et al. Characterization of the Analgesic and Anti-Inflammatory Activities of Ketorolac and Its Enantiomers in the Rat. J. Pharmacol. Exp. Ther. 1999, 288, 1288-1297. [PubMed]

54. Kean, W.F.; Lock, C.J.L.; Rischke, J.; Butt, R.; Buchanan, W.W.; Howard-Lock, H. Effect of R and S Enantiomers of Naproxen on Aggregation and Thromboxane Production in Human Platelets. J. Pharm. Sci. 1989, 78, 324-327. [CrossRef] [PubMed] 
55. Kean, W.F.; Howard-Lock, H.E.; Lock, C.J.L. Chirality in antirheumatic drugs. Lancet 1991, 338, $1565-1568$. [CrossRef]

56. Mroszczak, E.; Combs, D.; Chaplin, M.; Tsina, I.; Tarnowski, T.; Rocha, C.; Tam, Y.; Boyd, A.; Young, J.; Depass, L. Chiral Kinetics and Dynamics of Ketorolac. J. Clin. Pharmacol. 1996, 36, 521-539. [CrossRef] [PubMed]

57. Inoue, T.; Murano, M.; Yoda, Y.; Kuramoto, T.; Kakimoto, K.; Ishida, K.; Kawakami, K.; Abe, Y.; Morita, E.; Murano, N.; et al. R-etodolac induces E-cadherin and suppresses colitis-related mouse colon tumorigenesis. Oncol. Rep. 2010, 24, 1487-1492.

58. Liu, J.K.; Patel, S.K.; Gillespie, D.L.; Whang, K.; Couldwell, W.T. R-flurbiprofen, a novel nonsteroidal anti-inflammatory drug, decreases cell proliferation and induces apoptosis in pituitary adenoma cells In Vitro. J. Neuro-Oncol. 2012, 106, 561-569. [CrossRef]

59. Schmitz, K.; de Bruin, N.; Bishay, P.; Männich, J.; Häussler, A.; Altmann, C.; Ferreirós, N.; Lötsch, J.; Ultsch, A.; Parnham, M.J.; et al. R-flurbiprofen attenuates experimental autoimmune encephalomyelitis in mice. EMBO Mol. Med. 2014, 6, 1398-1422. [CrossRef]

60. Geerts, H. Drug evaluation: (R)-flurbiprofen-An enantiomer of flurbiprofen for the treatment of Alzheimer's disease. IDrugs 2007, 10, 121-133.

61. Kolluri, S.K.; Corr, M.; James, S.Y.; Bernasconi, M.; Lu, D.; Liu, W.; Cottam, H.B.; Leoni, L.M.; Carson, D.A.; Zhang, X. The R-enantiomer of the nonsteroidal antiinflammatory drug etodolac binds retinoid X receptor and induces tumor-selective apoptosis. Proc. Natl. Acad. Sci. USA 2005, 102, 2525-2530. [CrossRef]

62. Yasui, H.; Hideshima, T.; Hamasaki, M.; Roccaro, A.M.; Shiraishi, N.; Kumar, S.; Tassone, P.; Ishitsuka, K.; Raje, N.; Tai, Y.-T.; et al. SDX-101, the R-enantiomer of etodolac, induces cytotoxicity, overcomes drug resistance, and enhances the activity of dexamethasone in multiple myeloma. Blood 2005, 106, 706-712. [CrossRef] [PubMed]

63. Oprea, T.I.; Sklar, L.A.; Agola, J.O.; Guo, Y.; Silberberg, M.; Roxby, J.; Vestling, A.; Romero, E.; Surviladze, Z.; Murray-Krezan, C.; et al. Novel Activities of Select NSAID R-Enantiomers against Rac1 and Cdc42 GTPases. PLoS ONE 2015, 10, e0142182. [CrossRef] [PubMed]

64. Guo, Y.; Kenney, S.R.; Muller, C.Y.; Adams, S.; Rutledge, T.; Romero, E.; Murray-Krezan, C.; Prekeris, R.; Sklar, L.A.; Hudson, L.G.; et al. R-Ketorolac Targets Cdc42 and Rac1 and Alters Ovarian Cancer Cell Behaviors Critical for Invasion and Metastasis. Mol. Cancer Ther. 2015, 14, 2215-2227. [CrossRef] [PubMed]

65. Roche Laboratories Toradol Oral (ketorolac tromethamine tablets). 1997-2013. Available online: https: //www.accessdata.fda.gov/drugsatfda_docs/label/2013/019645s019lbl.pdf (accessed on 3 January 2015).

66. Ulm, M.A.; ElNaggar, A.C.; Tillmanns, T.D. Celecoxib versus ketorolac following robotic hysterectomy for the management of postoperative pain: An open-label randomized control trial. Gynecol. Oncol. 2018, 151, 124-128. [CrossRef] [PubMed]

67. Minotti, V.; Betti, M.; Ciccarese, G.; Fumi, G.; Tonato, M.; Favero, A.D. A Double-Blind Study Comparing Two Single-Dose Regimens of Ketorolac with Diclofenac in Pain Due to Cancer. Pharmacother. J. Hum. Pharmacol. Drug Ther. 1998, 18, 504-508.

68. Jameel, A.; Stein, R.; Rawson, N.; Hedley, A.; Stuttaford, J.; Coombes, R. Comparative-study of intramuscular ketorolac tromethamine and morphine in patients experiencing cancer pain. Int. J. Oncol. 1995, 6, 1307-1311. [CrossRef]

69. Carlson, R.W.; Borrison, R.A.; Sher, H.B.; Eisenberg, P.D.; Mowry, P.A.; Wolin, E.M. A Multiinstitutional Evaluation of the Analgesic Efficacy and Safety of Ketorolac Tromethamine, Acetaminophen plus Codeine, and Placebo in Cancer Pain. Pharmacother. J. Hum. Pharmacol. Drug Ther. 1990, 10, 211-216.

70. Ketorolac for Pain Management: A Review of the Clinical Evidence; CADTH Rapid Response Reports; Canadian Agency for Drugs and Technologies in Health: Ottawa, ON, Canada, 2014. Available online: http: //www.ncbi.nlm.nih.gov/books/NBK254117/ (accessed on 20 June 2019).

71. Mercadante, S.; Giarratano, A. The long and winding road of non steroidal antinflammatory drugs and paracetamol in cancer pain management: A critical review. Crit. Rev. Oncol./Hematol. 2013, 87, 140-145. [CrossRef]

72. Santoso, J.T.; Ulm, M.A.; Jennings, P.W.; Wan, J.Y. Multimodal pain control is associated with reduced hospital stay following open abdominal hysterectomy. Eur. J. Obstet. Gynecol. Reprod. Biol. 2014, 183, 48-51. [CrossRef] 
73. Forget, P.; Vandenhende, J.; Berliere, M.; Machiels, J.-P.; Nussbaum, B.; Legrand, C.; Kock, M.D. Do Intraoperative Analgesics Influence Breast Cancer Recurrence After Mastectomy? A Retrospective Analysis. Anesth. Analg. 2010, 110, 1630-1635. [CrossRef]

74. Retsky, M.; Rogers, R.; Demicheli, R.; Hrushesky, W.J.; Gukas, I.; Vaidya, J.S.; Baum, M.; Forget, P.; DeKock, M.; Pachmann, K. NSAID analgesic ketorolac used perioperatively may suppress early breast cancer relapse: Particular relevance to triple negative subgroup. Breast Cancer Res. Treat. 2012, 134, 881-888. [CrossRef] [PubMed]

75. Retsky, M.; Demicheli, R.; Hrushesky, W.J.M.; Forget, P.; Kock, M.D.; Gukas, I.; Rogers, R.A.; Baum, M.; Vaidya, J.S. Reduction of Breast Cancer Relapses with Perioperative Non-Steroidal Anti-Inflammatory Drugs: New Findings and a Review. Curr. Med. Chem. 2013, 20, 4163-4176. [CrossRef] [PubMed]

76. Forget, P.; Machiels, J.-P.; Coulie, P.G.; Berliere, M.; Poncelet, A.J.; Tombal, B.; Stainier, A.; Legrand, C.; Canon, J.-L.; Kremer, Y.; et al. Neutrophil:Lymphocyte Ratio and Intraoperative Use of Ketorolac or Diclofenac are Prognostic Factors in Different Cohorts of Patients Undergoing Breast, Lung, and Kidney Cancer Surgery. Ann. Surg. Oncol. 2013, 20, 650-660. [CrossRef] [PubMed]

77. Desmedt, C.; Demicheli, R.; Fornili, M.; Bachir, I.; Duca, M.; Viglietti, G.; Berlière, M.; Piccart, M.; Sotiriou, C.; Sosnowski, M.; et al. Potential Benefit of Intra-Operative Administration of Ketorolac on Breast Cancer Recurrence According to the Patient's Body Mass Index. J. Natl. Cancer Inst. 2018, 110, 1115-1122. [CrossRef] [PubMed]

78. Guo, Y.; Kenney, S.R.; Cook, L.; Adams, S.F.; Rutledge, T.; Romero, E.; Oprea, T.I.; Sklar, L.A.; Bedrick, E.; Wiggins, C.L.; et al. A novel pharmacologic activity of ketorolac for therapeutic benefit in ovarian cancer patients. Clin. Cancer Res. 2015, 21, 5064-5072. [CrossRef] [PubMed]

79. Forget, P.; Tombal, B.; Scholtès, J.-L.; Nzimbala, J.; Meulders, C.; Legrand, C.; Cangh, P.V.; Cosyns, J.-P.; Kock, M.D. Do intraoperative analgesics influence oncological outcomes after radical prostatectomy for prostate cancer? Eur. J. Anaesthesiol. 2011, 28, 830-835. [CrossRef] [PubMed]

80. Wuethrich, P.Y.; Schmitz, S.-F.H.; Kessler, T.M.; Thalmann, G.N.; Studer, U.E.; Stueber, F.; Burkhard, F.C. Potential Influence of the Anesthetic Technique Used during Open Radical Prostatectomy on Prostate Cancer-related OutcomeA Retrospective Study. Anesthesiol. J. Am. Soc. Anesthesiol. 2010, 113, 570-576.

81. Choi, J.E.; Villarreal, J.; Lasala, J.; Gottumukkala, V.; Mehran, R.J.; Rice, D.; Yu, J.; Feng, L.; Cata, J.P. Perioperative neutrophil:lymphocyte ratio and postoperative NSAID use as predictors of survival after lung cancer surgery: A retrospective study. Cancer Med. 2015, 4, 825-833. [CrossRef]

82. Savant, S.S.; Sriramkumar, S.; O'Hagan, H.M. The Role of Inflammation and Inflammatory Mediators in the Development, Progression, Metastasis, and Chemoresistance of Epithelial Ovarian Cancer. Cancers 2018, 10, 251. [CrossRef]

83. Ali-Fehmi, R.; Morris, R.T.; Bandyopadhyay, S.; Che, M.; Schimp, V.; Malone, J.M.; Munkarah, A.R. Expression of cyclooxygenase- 2 in advanced stage ovarian serous carcinoma: Correlation with tumor cell proliferation, apoptosis, angiogenesis, and survival. Am. J. Obstet. Gynecol. 2005, 192, 819-825. [CrossRef]

84. Rask, K.; Zhu, Y.; Wang, W.; Hedin, L.; Sundfeldt, K. Ovarian epithelial cancer: A role for PGE2-synthesis and signalling in malignant transformation and progression. Mol. Cancer 2006, 5, 62. [CrossRef] [PubMed]

85. Menczer, J.; Schreiber, L.; Kravtsov, V.; Berger, E.; Golan, A.; Levy, T. Cox-2 immunohistochemical expression in epithelial ovarian carcinoma and platin sensitivity. Eur. J. Gynaecol. Oncol. 2009, 30, 531-535. [PubMed]

86. Steffensen, K.D.; Waldstrøm, M.; Jeppesen, U.; Jakobsen, E.; Brandslund, I.; Jakobsen, A. The prognostic importance of cyclooxygenase 2 and HER2 expression in epithelial ovarian cancer. Int. J. Gynecol. Cancer 2007, 17, 798-807. [CrossRef] [PubMed]

87. Athanassiadou, P.; Grapsa, D.; Athanassiades, P.; Gonidi, M.; Athanassiadou, A.-M.; Tsipis, A.; Patsouris, E. The prognostic significance of COX-2 and survivin expression in ovarian cancer. Pathol.-Res. Pract. 2008, 204, 241-249. [CrossRef] [PubMed]

88. Beeghly-Fadiel, A.; Wilson, A.J.; Keene, S.; El Ramahi, M.; Xu, S.; Marnett, L.J.; Fadare, O.; Crispens, M.A.; Khabele, D. Differential cyclooxygenase expression levels and survival associations in type I and type II ovarian tumors. J. Ovarian Res. 2018, 11, 17. [CrossRef] [PubMed]

89. Wilson, A.J.; Fadare, O.; Beeghly-Fadiel, A.; Son, D.-S.; Liu, Q.; Zhao, S.; Saskowski, J.; Uddin, M.J.; Daniel, C.; Crews, B.; et al. Aberrant over-expression of COX-1 intersects multiple pro-tumorigenic pathways in high-grade serous ovarian cancer. Oncotarget 2015, 6, 21353-21368. [CrossRef] [PubMed] 
90. Zhang, D.; Bai, B.; Xi, Y.; Wang, T.; Zhao, Y. Is aspirin use associated with a decreased risk of ovarian cancer? A systematic review and meta-analysis of observational studies with dose-response analysis. Gynecol. Oncol. 2016, 142, 368-377. [CrossRef]

91. Verdoodt, F.; Kjaer, S.K.; Friis, S. Influence of aspirin and non-aspirin NSAID use on ovarian and endometrial cancer: Summary of epidemiologic evidence of cancer risk and prognosis. Maturitas 2017, 100,1-7. [CrossRef] [PubMed]

92. Verdoodt, F.; Dehlendorff, C.; Friis, S.; Kjaer, S.K. Non-aspirin NSAID use and ovarian cancer mortality. Gynecol. Oncol. 2018, 150, 331-337. [CrossRef]

93. Peres, L.C.; Camacho, F.; Abbott, S.E.; Alberg, A.J.; Bandera, E.V.; Barnholtz-Sloan, J.; Bondy, M.; Cote, M.L.; Crankshaw, S.; Funkhouser, E.; et al. Analgesic medication use and risk of epithelial ovarian cancer in African American women. Br. J. Cancer 2016, 114, 819-825. [CrossRef]

94. Nagle, C.M.; Ibiebele, T.I.; DeFazio, A.; Protani, M.M.; Webb, P.M. Aspirin, nonaspirin nonsteroidal anti-inflammatory drugs, acetaminophen and ovarian cancer survival. Cancer Epidemiol. 2015, 39, $196-199$. [CrossRef] [PubMed]

95. Dixon, S.C.; Nagle, C.M.; Wentzensen, N.; Trabert, B.; Beeghly-Fadiel, A.; Schildkraut, J.M.; Moysich, K.B.; deFazio, A.; Risch, H.A.; Rossing, M.A.; et al. Use of common analgesic medications and ovarian cancer survival: Results from a pooled analysis in the Ovarian Cancer Association Consortium. Br. J. Cancer 2017, 116, 1223-1228. [CrossRef] [PubMed]

96. Barnard, M.E.; Poole, E.M.; Curhan, G.C.; Eliassen, A.H.; Rosner, B.A.; Terry, K.L.; Tworoger, S.S. Association of Analgesic Use with Risk of Ovarian Cancer in the Nurses' Health Studies. JAMA Oncol. 2018, 4, 1675-1682. [CrossRef] [PubMed]

97. Trabert, B.; Poole, E.M.; White, E.; Visvanathan, K.; Adami, H.-O.; Anderson, G.L.; Brasky, T.M.; Brinton, L.A.; Fortner, R.T.; Gaudet, M.; et al. Analgesic Use and Ovarian Cancer Risk: An Analysis in the Ovarian Cancer Cohort Consortium. J. Natl. Cancer Inst. 2018, 111, 137-145. [CrossRef] [PubMed]

98. Olsen, S.R. Taxanes and COX-2 inhibitors: From molecular pathways to clinical practice. Biomed. Pharmacother. 2005, 59, S306-S310. [CrossRef]

99. Reyners, A.K.L.; de Munck, L.; Erdkamp, F.L.G.; Smit, W.M.; Hoekman, K.; Lalisang, R.I.; de Graaf, H.; Wymenga, A.N.M.; Polee, M.; Hollema, H.; et al. A randomized phase II study investigating the addition of the specific COX-2 inhibitor celecoxib to docetaxel plus carboplatin as first-line chemotherapy for stage IC to IV epithelial ovarian cancer, Fallopian tube or primary peritoneal carcinomas: The DoCaCel study. Ann. Oncol. 2012, 23, 2896-2902.

100. Gartung, A.; Yang, J.; Sukhatme, V.P.; Bielenberg, D.R.; Fernandes, D.; Chang, J.; Schmidt, B.A.; Hwang, S.H.; Zurakowski, D.; Huang, S.; et al. Suppression of chemotherapy-induced cytokine/lipid mediator surge and ovarian cancer by a dual COX-2/sEH inhibitor. Proc. Natl. Acad. Sci. USA 2019, 116, 1698-1703. [CrossRef] [PubMed]

101. Ridley, A.J. Rho GTPase signalling in cell migration. Curr. Opin. Cell Biol. 2015, 36, 103-112. [CrossRef]

102. Jansen, S.; Gosens, R.; Wieland, T.; Schmidt, M. Paving the Rho in cancer metastasis: Rho GTPases and beyond. Pharmacol. Ther. 2018, 183, 1-21. [CrossRef]

103. Haga, R.B.; Ridley, A.J. Rho GTPases: Regulation and roles in cancer cell biology. Small GTPases 2016, 7 , 207-221. [CrossRef]

104. Lawson, C.D.; Ridley, A.J. Rho GTPase signaling complexes in cell migration and invasion. J. Cell Biol. 2018, 217, 447-457. [CrossRef] [PubMed]

105. Hudson, L.G.; Gillette, J.M.; Kang, H.; Rivera, M.R.; Wandinger-Ness, A. Ovarian Tumor Microenvironment Signaling: Convergence on the Rac1 GTPase. Cancers 2018, 10, 358. [CrossRef] [PubMed]

106. Kazanietz, M.G.; Caloca, M.-J. The Rac GTPase in cancer: From old concepts to new paradigms. Cancer Res. 2017, 77, 5445-5451. [CrossRef] [PubMed]

107. Aspenström, P. Activated Rho GTPases in Cancer-The Beginning of a New Paradigm. Int. J. Mol. Sci. 2018, 19, 3949. [CrossRef] [PubMed]

108. Maldonado, M.D.M.; Dharmawardhane, S. Targeting Rac and Cdc42 GTPases in Cancer. Cancer Res. 2018, 78, 3101-3111. [CrossRef] [PubMed]

109. Cardama, G.A.; Alonso, D.F.; Gonzalez, N.; Maggio, J.; Gomez, D.E.; Rolfo, C.; Menna, P.L. Relevance of small GTPase Rac1 pathway in drug and radio-resistance mechanisms: Opportunities in cancer therapeutics. Crit. Rev. Oncol./Hematol. 2018, 124, 29-36. [CrossRef] [PubMed] 
110. Lou, S.; Wang, P.; Yang, J.; Ma, J.; Liu, C.; Zhou, M. Prognostic and Clinicopathological Value of Rac1 in Cancer Survival: Evidence from a Meta-Analysis. J. Cancer 2018, 9, 2571-2579. [CrossRef]

111. Leng, R.; Liao, G.; Wang, H.; Kuang, J.; Tang, L. Rac1 expression in epithelial ovarian cancer: Effect on cell EMT and clinical outcome. Med. Oncol. 2015, 32, 28. [CrossRef]

112. Cardama, G.A.; Gonzalez, N.; Maggio, J.; Menna, P.L.; Gomez, D.E. Rho GTPases as therapeutic targets in cancer (Review). Int. J. Oncol. 2017, 51, 1025-1034. [CrossRef]

113. Lin, Y.; Zheng, Y. Approaches of targeting Rho GTPases in cancer drug discovery. Expert Opin. Drug Discov. 2015, 10, 991-1010. [CrossRef]

114. Pajic, M.; Herrmann, D.; Vennin, C.; Conway, J.R.; Chin, V.T.; Johnsson, A.-K.E.; Welch, H.C.; Timpson, P. The dynamics of Rho GTPase signaling and implications for targeting cancer and the tumor microenvironment. Small GTPases 2015, 6, 123-133. [CrossRef] [PubMed]

115. Zandvakili, I.; Lin, Y.; Morris, J.C.; Zheng, Y. Rho GTPases: Anti- or Pro-Neoplastic Targets? Oncogene 2017, 36, 3213-3222. [CrossRef] [PubMed]

116. Smithers, C.C.; Overduin, M. Structural Mechanisms and Drug Discovery Prospects of Rho GTPases. Cells 2016, 5, 26. [CrossRef] [PubMed]

117. Fang, D.; Chen, H.; Zhu, J.Y.; Wang, W.; Teng, Y.; Ding, H.-F.; Jing, Q.; Su, S.-B.; Huang, S. Epithelial-mesenchymal transition of ovarian cancer cells is sustained by Rac1 through simultaneous activation of MEK1/2 and Src signaling pathways. Oncogene 2017, 36, 1546-1558. [CrossRef] [PubMed]

118. Zhou, G.; Peng, F.; Zhong, Y.; Chen, Y.; Tang, M.; Li, D. Rhein suppresses matrix metalloproteinase production by regulating the Rac1/ROS/MAPK/AP-1 pathway in human ovarian carcinoma cells. Int. J. Oncol. 2017, 50, 933-941. [CrossRef]

119. Hong, L.; Kenney, S.R.; Phillips, G.K.; Simpson, D.; Schroeder, C.E.; Nöth, J.; Romero, E.; Swanson, S.; Waller, A.; Strouse, J.J.; et al. Characterization of a Cdc42 Protein Inhibitor and Its Use as a Molecular Probe. J. Biol. Chem. 2013, 288, 8531-8543. [CrossRef]

120. Rivera, M.; Dominguez, D.; Pauken, C.; Romero, E.; Kenney, S.R.; Shi, Y.; Lee, J.-H.; Gillette, J.; Hudson, L.G.; Wandinger-Ness, A. Abstract 3159: Rac1 and Cdc42 as drivers in ovarian cancer metastasis. Cancer Res. 2018, 78,3159 .

121. Luo, W.; Brouwer, C. Pathview: An R/Bioconductor package for pathway-based data integration and visualization. Bioinformatics 2013, 29, 1830-1831. [CrossRef]

122. Luo, W.; Friedman, M.S.; Shedden, K.; Hankenson, K.D.; Woolf, P.J. GAGE: Generally applicable gene set enrichment for pathway analysis. BMC Bioinform. 2009, 10, 161. [CrossRef]

123. Huang, D.W.; Sherman, B.T.; Lempicki, R.A. Systematic and integrative analysis of large gene lists using DAVID bioinformatics resources. Nat. Protoc. 2009, 4, 44-57. [CrossRef]

124. Huang, D.W.; Sherman, B.T.; Lempicki, R.A. Bioinformatics enrichment tools: Paths toward the comprehensive functional analysis of large gene lists. Nucleic Acids Res. 2009, 37, 1-13. [CrossRef]

125. Earp, M.; Tyrer, J.; Winham, S.J.; Lin, H.-Y.; Chornokur, G.; Dennis, J.; Aben, K.K.; Anton-Culver, H.; Antonenkova, N.; Bandera, E.V.; et al. Variants in genes encoding small GTPases and association with epithelial ovarian cancer susceptibility. PLoS ONE 2018, 13, e0197561. [CrossRef] [PubMed]

126. Panigrahy, D.; Gartung, A.; Yang, J.; Yang, H.; Gilligan, M.M.; Sulciner, M.L.; Bhasin, S.S.; Bielenberg, D.R.; Chang, J.; Schmidt, B.A.; et al. Preoperative stimulation of resolution and inflammation blockade eradicates micrometastases. J. Clin. Investig. 2019, 130. [CrossRef] [PubMed]

127. Nguyen, B.C.Q.; Takahashi, H.; Uto, Y.; Shahinozzaman, M.D.; Tawata, S.; Maruta, H. 1,2,3-Triazolyl ester of Ketorolac: A “Click Chemistry"-based highly potent PAK1-blocking cancer-killer. Eur. J. Med. Chem. 2017, 126, 270-276. [PubMed]

128. Ahn, M.-R.; Bae, J.-Y.; Jeong, D.-H.; Takahashi, H.; Uto, Y.; Maruta, H. Both triazolyl ester of ketorolac (15K) and YM155 inhibit the embryonic angiogenesis in ovo (fertilized eggs) via their common PAK1-survivin/VEGF signaling pathway. Drug Discov. Ther. 2017, 11, 300-306. [CrossRef]

(C) 2019 by the authors. Licensee MDPI, Basel, Switzerland. This article is an open access article distributed under the terms and conditions of the Creative Commons Attribution (CC BY) license (http://creativecommons.org/licenses/by/4.0/). 